\title{
NITROBENZENE REDUCTION CATALIZED BY SOLUBLE CARBONYLRHODIUM COMPLEXES OF METHYL AND DIMETHYL PYRIDINE LIGANDS
}

\author{
M. BARTOLINI', J. MOLINA ${ }^{1}$, M. C. ORTEGA ${ }^{1}$, P. SOJO ${ }^{1}$, A. J. PARDEY $Y^{1 . *}$, C. LONGO2, \\ S.A. MOYA ${ }^{3}$, R. P. FEAZELL $L^{4}$
}

${ }^{1}$ Centro de Equilibrios en Solución, Escuela de Química, Facultad de Ciencias, Universidad Central de Venezuela, Caracas, Venezuela ${ }^{2}$ Centro de Investigación y Desarrollo de Radiofármacos, Facultad de Farmacia, Universidad Central de Venezuela, Caracas, Venezuela ${ }^{3}$ Departamento de Química de los Materiales, Facultad de Química y Biología, Universidad de Santiago de Chile, Santiago, Chile ${ }^{4}$ Department of Chemistry, Massachusetts Institute of Technology, Cambridge, Massachusetts 02139, USA

(Received $28^{\text {th }}$ March 2007 - Accepted $15^{\text {th }}$ June 2007)

\begin{abstract}
The catalytic reduction of nitrobenzene by rhodium(I) complexes of the type $c i s-\left[\mathrm{Rh}(\mathrm{CO})_{2}\left(\mathrm{amine}_{2}\right]\left(\mathrm{PF}_{6}\right)\right.$ (amine $=2$-methylpyridine, 3-methylpyridine, 4-methylpyridine, or 2,6-dimethylpyridine) in methanol under an atmosphere of carbon monoxide is described. A single organic product, aniline, is seen in the post-reaction mixture. The amount of product formed depends upon the nature of the amine coordinated to the rhodium center.
\end{abstract}

Key Words: Catalysis, nitrobenzene reduction, rhodium complexes; carbon monoxide.

\section{INTRODUCTION}

Interests in the catalytic reduction of nitrobenzene to aniline under an atmosphere of $\mathrm{CO} / \mathrm{H}_{2} \mathrm{O}$ (Eq. [1]), promoted by transition metal complexes, has been shown in several recent investigations due to the great potential of this reaction for industrial applications. ${ }^{1-3}$

$$
\mathrm{C}_{6} \mathrm{H}_{5} \mathrm{NO}_{2}+3 \mathrm{CO}+\mathrm{H}_{2} \mathrm{O} \longrightarrow \mathrm{C}_{6} \mathrm{H}_{5} \mathrm{NH}_{2}+3 \mathrm{CO}_{2}
$$

The nature of the metal-containing active species formed by the catalysts during the reduction of such aromatic nitro compounds by $\mathrm{CO}$ and $\mathrm{H}_{2} \mathrm{O}$ was partially dealt with in a review by Nomura ${ }^{4}$.

The ability of soluble cationic carbonylrhodium(I) complexes of pyridine and related ligands to be applied as catalysts for the carbonylation of methanol has been demonstrated ${ }^{5}$, as has their ability to function as catalysts for the oligomerization of $\mathrm{CO} /$ ethylene $^{6}$ and the hydroformylation-acetalization of 1-hexene ${ }^{7}$. The utility of these types of complexes in the preceding reactions have been realized due, in part, to their easy preparation, good stability, high or moderate catalytic activities and the fine balance that is had between the electronic and steric effects induced by the methyl group on the pyridinic ring.

Work in our laboratories have long been concerned with the use of soluble $c i s-\left[\mathrm{Rh}(\mathrm{CO})_{2}(\text { amine })_{2}\right]\left(\mathrm{PF}_{6}\right)$ complexes (amine $=2$-methylpyridine, 3 methylpyridine, 4-methylpyridine, or 2,6-dimethylpyridine) or the analogous complexes immobilized on poly(4-vinylpyridine) as catalysts for the reduction of nitrobenzene $e^{8-10}$ and nitrofurans ${ }^{11}$ under $\mathrm{CO} / \mathrm{H}_{2} \mathrm{O}$. However, little is known about the cabonylation of nitrobenzene by these $\mathrm{Rh}$ /pyridine systems in an alcoholic solvent under a $\mathrm{CO}$ atmosphere.

We report in the present study the influence of the nature of the coordinated methyl- or dimethylamine on the catalytic reduction of nitrobenzene to aniline by these rhodium(I) complexes.

\section{EXPERIMENTAL}

Materials: methyl pyridines and 2,6-dimethyl pyridine were obtained from Aldrich and distilled over $\mathrm{KOH}$. Methanol (Aldrich) was distilled prior to use. Nitrobenzene (Aldrich) was distilled from $\mathrm{H}_{2} \mathrm{SO}_{4}(1 \mathrm{M})$ and redistilled from $\mathrm{CaCl}_{2}$ before use. All gas mixtures $\left(\mathrm{He} / \mathrm{H}_{2}(91.4 \% / 8.6 \%, \mathrm{v} / \mathrm{v}), \mathrm{CO} / \mathrm{CH}_{4}\right.$ $(95.8 \% / 4.2 \%, \mathrm{v} / \mathrm{v})$ and $\mathrm{CO} / \mathrm{CH}_{4} / \mathrm{CO}_{2} / \mathrm{H}_{2}(84.8 \% / 5.1 \% / 5.3 \% / 4.8 \%$, v/v)) were purchased from BOC Gases and used as received. Metal complexes of the type cis- $\left[\mathrm{Rh}(\mathrm{CO})_{2}(\text { amine })_{2}\right]\left(\mathrm{PF}_{6}\right)$ (amine = 2-methylpyridine, 3-methylpyridine, 4-methylpyridine, or 2,6-dimethylpyridine) were synthesized and characterized as reported by Denise and Pannetier ${ }^{12}$ and their identity and purity confirmed by their IR spectra in chloroform (two strong bands in the $v_{(\mathrm{CO})}$ region at 2095 and $2020 \mathrm{~cm}^{-1}$ ).
Instrumentation: Gas sample analyses from catalysis runs were performed as previously detailed ${ }^{13}$ on a Hewlett-Packard 5890 Series II programmable (ChemStation) gas chromatograph equipped with a thermal conductivity detector. The column employed was Carbosieve-B (80-100 mesh) obtained from HewlettPackard. The instrument was programmed with a temperature ramp from 60 to $175{ }^{\circ} \mathrm{C}$ at a $\mathrm{He} / \mathrm{H}_{2}$ carrier-gas flow rate of $50 \mathrm{~mL} / \mathrm{min}$. Analyses of the liquid phases were done on a Buck Scientific 910 programmable gas chromatograph equipped with an apiezonl column and a flame ionization detector. The instrument was ramped from 60 to $160{ }^{\circ} \mathrm{C}$ at a $\mathrm{He}$ carrier-gas flow rate of $30 \mathrm{~mL} / \mathrm{min}$. A Hewlett-Packard 6890 Series programmable gas chromatograph fitted with a HP-1 (crosslinked methylsiloxane) ( $10 \mathrm{~m} \times 0.25 \mathrm{~mm} \times 0.5 \mu \mathrm{m})$ column was used to confirm the identity of the organic reaction products at the end of each run. The organic product was also separated by column chromatography and analyzed by ${ }^{13} \mathrm{C}$ and ${ }^{1} \mathrm{H}-\mathrm{NMR}$ in a Jeol Eclipse 270 NMR spectrometer $\left(\delta_{\mathrm{C}}=\right.$ $146.6,129.3,118.4$ and $115.1 \mathrm{ppm}$ and $\delta_{\mathrm{H}}=7.1,6.7,6.6$ and $3.6 \mathrm{ppm}$ ).

Catalytic tests: Catalytic runs were carried out in a $30 \mathrm{~mL}$ mechanically stirred stainless steel Parr autoclave charged with $1 \times 10^{-4} \mathrm{~mol}$ of the cis$\left.\left[\mathrm{Rh}(\mathrm{CO})_{2} \text { (amine }\right)_{2}\right]\left(\mathrm{PF}_{6}\right)$ complexes, $10 \mathrm{~mL}$ of methanol, $0.26 \mathrm{~mL}\left(2 \times 10^{-3} \mathrm{~mol}\right)$ of nitrobenzene pressurized with $\mathrm{CO} / \mathrm{CH}_{4}(30 \mathrm{~atm})$. The autoclave was placed in a temperature-controlled heating device at $150 \pm 1{ }^{\circ} \mathrm{C}$ and mechanically stirred for $6 \mathrm{~h}$. These pressures and temperatures were chosen by taking an average from previously reported systems..$^{14}$ At the end of the set reaction time gas and liquid samples were taken and analyzed by GC. Identity of the products was confirmed by GC-MS. A response factor method for the GC analyses of the aniline was employed. ${ }^{15}$ The GC-MS spectrum of the aniline (molecular ion peak at $\mathrm{m} / \mathrm{e}=93$ and base peak at $\mathrm{m} / \mathrm{e}=66$ ) product is comparable to the obtained from a pure sample of aniline. Methane was used as an internal standard to allow calculation of absolute quantities of $\mathrm{CO}$ consumed and $\mathrm{CO}_{2}$ produced in $6 \mathrm{~h}$ with calibration curves being prepared periodically for $\mathrm{CO}^{2}$, $\mathrm{CH}_{4}$ and $\mathrm{CO}_{2}$.

\section{RESULTS AND DISCUSSION}

The cis- $\left[\mathrm{Rh}(\mathrm{CO})_{2}(\text { amine })_{2}\right]\left(\mathrm{PF}_{6}\right)$ complexes were examined as catalytic precursors for the reduction of nitrobenzene to aniline under $\mathrm{CO}$. The results are summarized in Table I. Control experiments showed no reduction of nitrobenzene to aniline under $\mathrm{CO}$ when a mixture of methanol and nitrobenzene were exposed to similar experimental conditions as those in our catalytic tests in the absence of one of our carbonylrhodium catalysts. Even though the reagents and solvents used were pre-dried some residual water always remained. In addition, in situ generation of water occurred via methanol dimerization, Eq. [2], under the catalytic conditions $\left(150^{\circ} \mathrm{C}\right)$. The $\mathrm{GC}$ analyses of the gas phase of the catalytic runs allowed for the identification of $\mathrm{CO}_{2}$ as a sole gaseous product in accordance with Eq. [1]. The relative amounts of aniline and $\mathrm{CO}_{2}$ produced matched stoichiometrically as required by Eq. [1] $\left(\mathrm{CO}_{2} /\right.$ aniline ca. 3.1).

$$
2 \mathrm{CH}_{3} \mathrm{OH} \longrightarrow \mathrm{H}_{2} \mathrm{O}+\mathrm{CH}_{3} \mathrm{OCH}_{3}
$$


Table I. Reduction of nitrobenzene by cis-[Rh(CO) $\left.(\text { amine })_{2}\right]\left(\mathrm{PF}_{6}\right)$ complexes under $\mathrm{CO} / \mathrm{H}_{2} \mathrm{O}^{\mathrm{a}}$.

\begin{tabular}{|c|c|c|c|c|}
\hline $\begin{array}{c}\text { Amine } \\
(\mathrm{pKa})^{\mathrm{b}}\end{array}$ & $\begin{array}{c}\text { Yield of } \\
\mathrm{CO}_{2} \\
\left(\mathrm{~mol}^{-3}\right. \\
\left.10^{-3}\right)^{\mathrm{c}}\end{array}$ & $\begin{array}{c}\text { Yield of } \\
\text { aniline } \\
(\mathrm{mol} \mathrm{x} \\
\left.10^{-3}\right)^{\mathrm{c}}\end{array}$ & $\begin{array}{c}\text { Nitrobenzene } \\
\text { conversion } \\
(\%)^{\mathrm{c}}\end{array}$ & $\mathrm{TF}(\text { aniline })^{\mathrm{d}}$ \\
\hline $\begin{array}{c}\text { 3-methylpyridine } \\
(5.52)\end{array}$ & 5.9 & 1.9 & 100 & 315 \\
\hline $\begin{array}{c}\text { 2-methylpyridine } \\
(5.97)\end{array}$ & 1.1 & 0.4 & 16 & 64 \\
\hline $\begin{array}{c}\text { 4-methylpyridine } \\
(6.00)\end{array}$ & 5.8 & 2.0 & 100 & 385 \\
\hline $\begin{array}{c}\text { 2,6- } \\
\text { dimethylpyridine } \\
(6.75)\end{array}$ & 2.8 & 0.9 & 49 & 124 \\
\hline
\end{tabular}

${ }^{a}[\mathrm{Rh}]=1 \times 10^{-4} \mathrm{~mol}, 0.26 \mathrm{~mL}\left(2 \times 10^{-3} \mathrm{~mol}\right)$ of nitrobenzene, 4-nitrobenzene $/ \mathrm{Rh}$ molar ratio $=25,10 \mathrm{~mL}$ of methanol, $\mathrm{P}(\mathrm{CO})=30$ atm at $150^{\circ} \mathrm{C}$ by $6 \mathrm{~h}$.

${ }^{\mathrm{b}}$ From Ref. [12].

${ }^{\mathrm{c} A f t e r} 6 \mathrm{~h}$.

${ }^{\mathrm{d}} \mathrm{TF}($ aniline $)=[(\mathrm{mol}$ of aniline $) /((\mathrm{mol}$ of $\mathrm{Rh}) \times(\mathrm{rt}))] \times 24 \mathrm{~h}$, where $(\mathrm{rt})=$ reaction time in hours. Experimental uncertainty $<10 \%$.

The results show that the turnover frequency per day values $(\mathrm{TF}$ (aniline) $/ 24$ h) depend on the nature of the coordinated amine and decrease in the following order: 4-methylpyridine $>3$-methylpyridine $>2$,6-dimethylpyridine $>2$ methylpyridine. Accordingly, the catalytic nitrobenzene reduction by these $\mathrm{Rh}$ (amine) ${ }_{2}$ complexes appears influenced by the basic nature of the amine, with the $\mathrm{Rh}$ (4-methylpyridine) ${ }_{2}$ system the most active. The observed reverse order in the case of the $\mathrm{Rh}(2$-methylpyridine), system is likely due to the steric factor which overwhelms the electronics of the ligands. It is interesting to see on the $\mathrm{Rh}$ (2,6-dimethylpyridine) ${ }_{2}$ system that the steric factor does not completely overwhelm the electronic factor although the 2,6-dimethylpyridine amine sterically crowds the metal center more than any other amine used in this work. Surprisingly, these results are different from the previous results reported on the catalytic reduction of nitrobenzene to aniline by the $\mathrm{Rh}$ (amine) $)_{2}$ system under $\mathrm{CO}$ in aqueous amine solution ${ }^{8}$. The activity of the $\mathrm{Rh}$ (2-methylpyridine) $)_{2}$ complex was maximized (TF(aniline) $\left.42(24 \mathrm{~h})^{-1}\right)$ under the following conditions: $[\mathrm{Rh}]=10 \mathrm{mM}$, [substrate $] /[\mathrm{Rh}]=2500,8 \mathrm{~mL}$ of amine, $2 \mathrm{~mL}$ of $\mathrm{H}_{2} \mathrm{O}$, $\mathrm{P}(\mathrm{CO})=0.9 \mathrm{~atm}$ at $\mathrm{T}=100^{\circ} \mathrm{C}$ for $3 \mathrm{~h}$. As we can see, both $\mathrm{Rh} /$ aqueous amine and $\mathrm{Rh} /$ methanol catalytic system differ with the nature of the reaction medium and with the reaction conditions, with both having a strong influence on the reaction rate. It is likely that the nature of the catalytic species varies across the systems. In situ FT-IR and ${ }^{1} \mathrm{H}$ and ${ }^{13} \mathrm{C}$ characterization studies of these $\mathrm{Rh}$ (amine) $)_{2}$ /methanol system under $\mathrm{CO}$ are in progress and should give some insight on the nature of the catalytic intermediates. Similar studies of the $\mathrm{Rh}(\text { amine })_{2}$ /aquous amine system have revealed the presence of $\mathrm{Rh}-\mathrm{H}$ species as well as the formation of aminecarbonyl-Rh species with different nuclearities ${ }^{17,18}$.

The promoting effect of water in this reduction process has been related to the formation of an active rhodium-hydride $(\mathrm{Rh}-\mathrm{H})$ species (steps $2 \mathrm{~b}$ and $2 \mathrm{c}$, Scheme I), important steps in the catalytic cycle, via a reaction closely related to the water gas shift reaction (WGSR, Eq. [3]) ${ }^{19}$. Accordingly, it should be possible that these $\left(\mathrm{Rh}-\mathrm{H}\right.$ and $\left.\mathrm{Rh}-\mathrm{H}_{2}\right)$ species reacts with a rhodium-nitrene intermediate $\mathrm{e}^{20,21}$ (step 1e) to give aniline. Catalytic schemes for the reduction of nitrobenzene to aniline have been proposed in which nitrobenzene cycloaddition (step 1a) to a metal carbonyl complex is an important first step ${ }^{4}$. A detailed discussion of similar mechanistic schemes proposed for the reduction of nitro compounds under $\mathrm{CO} / \mathrm{H}_{2} \mathrm{O}$ catalyzed by rhodium ${ }^{2,11}$ and copper $^{3}$ complexes have been reported.

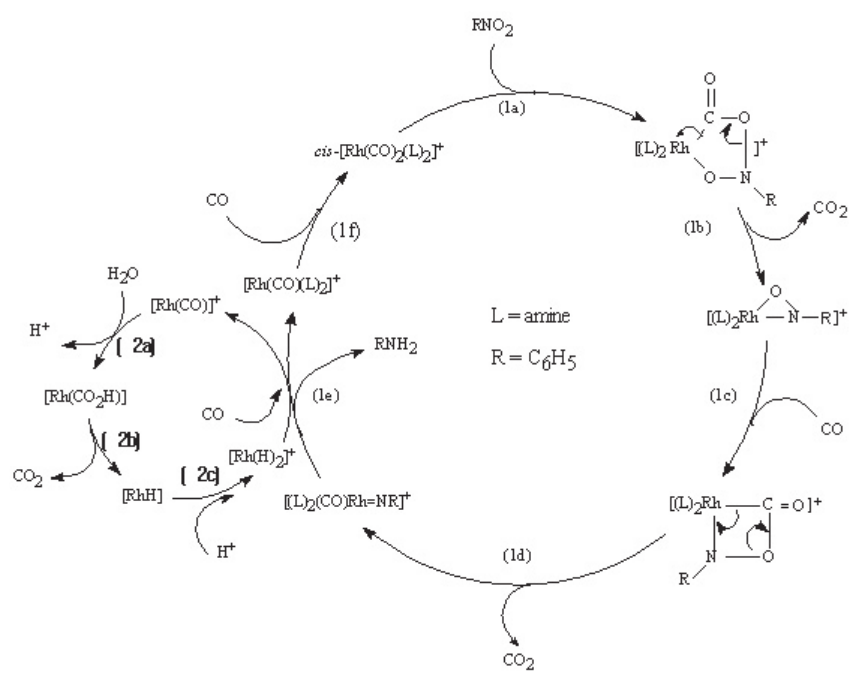

$\mathrm{CO}+\mathrm{H}_{2} \mathrm{O} \rightleftharpoons \mathrm{CO}_{2}+\mathrm{H}_{2}$

Eq. [3]

Scheme 1. Proposed mechanism.

The reductive carbonylation of nitrobenzene to $\mathrm{N}$-phenylmethylcarbamates in the presence of methanol under an atmosphere of CO catalyzed by rhodium complexes has been reported (Eq. [4]). ${ }^{14,22,23}$ With these $\mathrm{Rh}(\mathrm{amine})_{2}$ systems, however, such direct conversion of nitrobenzene to the carbamate was not observed, with aniline being the only observed product.

$\mathrm{C}_{6} \mathrm{H}_{5} \mathrm{NO}_{2}+3 \mathrm{CO}+\mathrm{CH}_{3} \mathrm{OH} \longrightarrow \mathrm{C}_{6} \mathrm{H}_{5} \mathrm{NHCO}_{2} \mathrm{CH}_{3}+2 \mathrm{CO}_{2}$

The absence of carbamate from the products of the reaction under $\mathrm{CO}$ pressure used in this work (30 atm) can be explained based not only on the fact that carbamates are usually formed under much higher $\mathrm{CO}$ pressures $(>$ $60 \mathrm{~atm})^{22,23}$ but also on the known ability of these $\mathrm{Rh}(\text { amine })_{2}$ system to be selective in their catalytic reduction of nitrobenzene to aniline in aqueous amine solutions ${ }^{8}$, as previously mentioned. The $\mathrm{Rh}(\text { amine })_{2} /$ methanol system favors the formation of aniline rather than the corresponding carbamate in the presence of trace amounts of water. In this case the role of the methanol is principally as a solvent for these rhodium complexes rather than to form a reactive compound (Eq. [4]). Accordingly, these results illustrate again the high selectivity of these $\mathrm{Rh}$ (amine) $)_{2}$ system for the catalytic reduction of nitrobenzene to aniline under $\mathrm{CO} / \mathrm{H}_{2} \mathrm{O}$.

It is worth mentioning that other kinds of amine ligands have been used in the reduction of nitrobenze to aniline by rhodium complexes. Namely, Kaneda et al. ${ }^{24}$, reported the use of following aliphatic amines in the presence of $\mathrm{Rh}_{6}(\mathrm{CO})_{16}$ under $\mathrm{CO}(0.9 \mathrm{~atm})$ at $80^{\circ} \mathrm{C}$ for $2.5,4$ or $10 \mathrm{~h}: \mathrm{NH}_{2}\left(\mathrm{CH}_{2}\right)_{2} \mathrm{NH}_{2}, \mathrm{NH}_{2}\left(\mathrm{CH}_{2}\right)_{3} \mathrm{NH}_{2}$, $\mathrm{NH}_{2}\left(\mathrm{CH}_{2}\right)_{4} \mathrm{NH}_{2}, \quad \mathrm{NH}_{2}\left(\mathrm{CH}_{2}\right) \mathrm{CH}\left(\mathrm{CH}_{3}\right) \mathrm{NH}_{2}, \quad \mathrm{NH}\left(\mathrm{CH}_{3}\right)\left(\mathrm{CH}_{2}\right)_{2} \mathrm{NH}\left(\mathrm{CH}_{3}\right)$, $\left(\mathrm{CH}_{3}\right)_{2} \mathrm{~N}\left(\mathrm{CH}_{2}\right)_{2} \mathrm{~N}\left(\mathrm{CH}_{3}\right)_{2}$ and $\left(\mathrm{CH}_{3}\right)_{2} \mathrm{~N}\left(\mathrm{CH}_{2}\right)_{3} \mathrm{~N}\left(\mathrm{CH}_{3}\right)_{2}$. They found that increasing the length of the hydrocarbon chain in $\mathrm{NH}_{2}\left(\mathrm{CH}_{2}\right)_{\mathrm{N}} \mathrm{NH}_{2}$ increases the conversion to aniline (from 34 to $50 \%$ ) and among the alkyldiamines, methyl substituents on the nitrogen promote the conversion (from 45 to $100 \%$ ). Alessio et al. ${ }^{25}$, reported the use of pyridine, 2,2'-bipyridine (bipy), 4,4'-Me bipy,

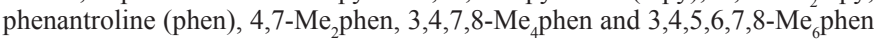
as ligands in the same type of reactions, observing a progressive increase of conversion to aniline (from $0,0.8,3.0,7.5,25,53$ to $73 \%$, respectively) in the presence of $\mathrm{Rh}_{6}(\mathrm{CO})_{16}$ under $\mathrm{CO}(30 \mathrm{~atm})$ at $165^{\circ} \mathrm{C}$. Unfortunately, $\mathrm{TF}$ (aniline) values were not reported in these two works negating any comparison with our catalytic system.

Ford, et. $\mathrm{al}^{2}$ also reported an efficient catalytic system based on $\mathrm{RhCl}_{3} /$ amine (amine $=$ diethylamine, trimethylamine, triethylamine, tetramethylenediamine, 2-methylamine, or tetramethylethylenediamine) for the reduction of nitrobenzene to aniline. The $\mathrm{TF}$ (aniline) $/ 24 \mathrm{~h}$ values followed the order tetr amethylethylenediamine $(131)>2$-methylamine $(78)>$ triethylamine $(31)>$ tetramethylenediamine $(20)>$ diethylamine $(17)>$ trimethylamine (13) under the following reaction conditions: $[\mathrm{Rh}]=5 \mathrm{mmol}, 10 \mathrm{~mL}$ of amine/water $8 / 2$ $(\mathrm{v} / \mathrm{v}), \mathrm{P}(\mathrm{CO})=0.9 \mathrm{~atm}$ at $100{ }^{\circ} \mathrm{C}$ for $3 \mathrm{~h}$. The reaction conditions used in the $\mathrm{RhCl}_{3} /$ amine catalytic system are milder than those employed in our $\mathrm{Rh}(\text { amine })_{2}$ 
catalytic system. The results show the $\mathrm{RhCl}_{3}$ /amine catalytic systems are more active than ours based on $\mathrm{Rh}$ (amine). However, in comparison with our system the former used a large amount of water which could affect a different mechanism of action and strongly influence the observed difference.

\section{ACKNOWLEDGMENTS}

The authors thank the CDCH-UCV (PI: 03.12.4229.98) and Fondecyt (1050168) for financial support.

\section{REFERENCES}

1. F. Ragaine, S. Cenini, M. Gaspari, J. Mol. Catal. A, 174, 51 (2001).

2. M. M. Mdleleni, R. G. Rinker, P.C. Ford, J. Mol. Catal. A 204-205, 125 (2003).

3. J. E. Yánez, A. B. Rivas, J. Alvarez, M. C. Ortega, A. J. Pardey, C. Longo, R. P. Feazell, J. Coord. Chem. 59, 1719 (2006).

4. K. Nomura, J. Mol. Catal. A, 130, 1 (1998).

5. N. Kumari, M. Sharma, P. Das, D.K. Dutta, Appl. Organomet. Chem. 16, $258(2002)$

6. A. J. Pardey, C. Longo, T. Funaioli, G. Fachinetti, Polyhedron. 23, 1677 (2004).

7. G.C. Uzcátegui, F. Hung, M.C. Ortega, A.J. Pardey, C. Longo, P. Aguirre, S.A. Moya, J. Chil. Chem. Soc. 50, 647 (2005).

8. C. Linares, M. Mediavilla, A. J. Pardey, P. Baricelli, C. Longo-Pardey, S. A. Moya, Catal. Lett. 50, 183 (1998).

9. M. Mediavilla, M. Fernández, A. J. Pardey, P. Baricelli, C. Longo, R. Sartori, S. A. Moya, Bol. Soc. Chil. Quím. 43, 359 (1998).
10. J. Mayora, M. Fernández, J. Alvarez, M. Ortega, A. J. Pardey, C. Longo, P. Baricelli, E. Lujano, S. A. Moya, Bol. Soc. Chil. Quím. 46,121 (2001).

11. M. E. Farkas, E. Rodríguez, C. Longo, M. Monasterios, M. C. Ortega, A. B. Rivas, R. López, A. J. Pardey, S. A. Moya, J. Chil. Chem. Soc, 51, 829 (2006).

12. B. Denise, G. Pannetier, J. Organomet. Chem. 63, 423 (1973).

13. A. J. Pardey, A. D. Rojas, J. E. Yanez, P. Betancourt, C. Scott, C. Chinea, C. Urbina, D. Moronta, C. Longo, Polyhedron. 24, 511 (2005).

14. T. Mizuno, H. Alper, J. Mol. Catal. A, 121, 119 (1997).

15. H. M. McNair, J. M. Miller, "Basic Gas Chromatography", WileyInterscience, New York, 1997, Ch. 8.

16. K. Schofield, "Hetero-Aromatic Nitrogen Compounds", Plenum Press, New York, 1967, pp. 146-148.

17. A. J. Pardey, P.C. Ford, J. Mol. Catal. 53, 247 (1989).

18. G. Fachinetti, T. Funaioli, P.F. Zanazzi, J. Organometal. Chem. 460, C34 (1993).

19. C. Longo, J. Alvarez, M. Fernández, A.J. Pardey, S.A. Moya, P. Baricelli, M.M. Mdleleni, Polyhedron. 19, 487 (2000).

20. P.C. Ford, A. Rokicki, Adv. Organomet. Chem. 28, 139 (1988)

21. F. Ragaini, S. Cenini, F. Demartin, Chem. Commun. 1467 (1992).

22. F. Ragaini, S. Cenini, Organometallics. 13, 1178 (1994).

23. S. Cenini, M. Pizzoti, C. Crotti, M. Pizzoti, F. Ragaini, F. Porta, J. Mol. Catal.49, 67 (1988).

24. K. Kaneda, M. Hiraki, T. Imanaka, S. Teranishi, J. Mol. Catal. 12, 385 (1981).

25. E. Alessio, F. Vinzi, G. Mestroni, J. Mol. Catal. 22, 327 (1984). 